\title{
The ECtHR's Jurisprudence on the Prohibition of Collective Expulsions in Cases of Pushbacks at European Borders: A Critical Perspective
}

\author{
Hanaa Hakiki"
}

There is surely no more burning issue in European politics today than the refoulement of migrants at land borders or in transit zones and the resulting State liability for human-rights breaches during immigration and border-control operations. Judge Pinto de Albuquerque ${ }^{1}$

\section{A. Introduction}

This article will focus first on the definition of the prohibition of collective expulsions provided by the European Convention for Human Rights ('ECHR') and through the European Court of Human Right's jurisprudence ('ECtHR') (A). Second, it will look at the exception to the applicability of the prohibition as defined by the Grand Chamber in N.D. and N.T. v. Spain ${ }^{2}$ (B). Third, the article will place the prohibition of collective expulsions as interpreted by Strasbourg in the wider framework of international human rights law $(\mathrm{C})$.

Article 4 protocol 4 of the ECHR reads 'collective expulsion of aliens is prohibited'. It was opened for signature in 1965 and has since been ratified by all state parties except Greece, Turkey, Switzerland and the United Kingdom. Initially, drafters intended article 4 protocol 4 ECHR to address the expulsion of legally residing non-nationals ${ }^{3}$ - now covered

* This article is the result of collective work, including research by Kristina Fried and comments by Carsten Gericke.

1 ECtHR, Judgment, 11 December 2018, M.A. and Others $v$ Lithuania, Application No. 59793/17, Dissenting Opinion, para. 1.

2 ECtHR, Judgment (GC), 13 February 2020, N.D. and N.T. $v$ Spain, Application Nos. 8675/15 and 8697/15.

3 The first Assembly draft of article 4 protocol 4 ECHR meant to restrict the possibility of expelling lawfully residing non-nationals to cases where (i) the lawful residency had lasted less than two years and (ii) there was a threat to national security 
under article 1 protocol 7 ECHR - but they then decided to word the provision in very broad terms. ${ }^{4}$

Non-nationals claimed their rights under the prohibition of collective expulsions soon after its first ratifications. ${ }^{5}$ Some of these early cases had already raised the issue of non-nationals' access to protection at borders. ${ }^{6}$ It was thus foreseeable that the intensification of European policies of border externalisation would lead to a greater relevance of the prohibition of collective expulsions in front of Strasbourg. In the last two decades European states have attempted to escape their legal obligation vis a vis refugees ${ }^{7}$ and migrants through the general use of fast-track readmission agreements on the one hand and the systematic use of irregular, summary and violent expulsions $^{8}$ on the other hand. An almost negligible number of those

or public order. However, the Committee of experts unanimously decided it was necessary to include an absolute prohibition on the collective expulsion of non-nationals. Further, the Committee noted that the expulsion of lawfully residing nonnationals was already addressed in another convention, deemed better to encroach upon States' discretion. See Council of Europe, Collected Edition of the "Travaux Préparatoires" of Protocol No. 4 (1976), 428 and $506 \mathrm{f}$.

4 For more details on the drafting process leading up to the current provision, please see Riemers, The Prohibition of Collective Expulsion in Public International Law (2020), 8 ff. and 76.

5 The first case in which article 4 protocol 4 ECHR was claimed was European Commission of Human Rights, Decision, 5 February 1973, X $v$ Sweden, Application No. 5525/72. The applicant was a stateless person facing expulsion to the United States after being convicted of theft. In fact, from the very first cases invoking this provision, the greatest majority of article 4 protocol 4 ECHR claims arise in pure immigration cases, with only a handful arising in the context of an ethnic minority facing forced displacement. Indeed the only such cases were ECtHR, Judgment, 5 February 2002, Conka v Belgium, Application No. 51564/99 and ECtHR, Judgment (GC), 3 July 2014, Georgia v Russia (I), Application No. 13255/07 followed by two cases in which the latter decision was applied, namely ECtHR, Judgment, 20 December 2016, Shioshvili and Others v Russia, Application No. 19356/07 and ECtHR, Judgment, 20 December 2016, Berdzenishvili and Others $v$ Russia, Application No. 14594/07. See also ECtHR, Guide on Article 4 of Protocol No. 4 to the European Convention on Human Rights, 31 August 2020, https://www.echr.coe.int/Docume nts/Guide_Art_4_Protocol_4_ENG.pdf, para. 10.

6 See European Commission of Human Rights, Decision, 14 October 1992, M. $v$ Denmark, Application No. 17392/90, where the provision was claimed by GDR citizens seeking to move to the Federal Republic of Germany through the Danish embassy in East Berlin.

7 See Hathaway and Gammeltoft-Hansen, 'Non-Refoulement in a World of Cooperative Deterrence' (2015) 53 n. 2, Colum. J. Transnat'l L., 235.

8 European Union Agency for Fundamental Rights, Fundamental Rights Report 2019 (2019), 131. 
subjected to such practices manage to take their cases to the ECtHR. This resulted in article 4 protocol 4 ECHR jurisprudence addressing a number of border situations, including fast-track (in)admission procedures on islands, ${ }^{9}$ refusals of entry at land border points, ${ }^{10}$ non-disembarkation at ports ${ }^{11}$ as well as summary push backs at land borders ${ }^{12}$ and on the high sea. ${ }^{13}$

The prohibition of collective expulsion of non-nationals is to be found in a number of international treaties ${ }^{14}$ and is accepted as a general principle of international law. ${ }^{15}$ Though distinct from the principle of non-refoulement - a cornerstone of the post-World War II refugee law regime - the prohibition of collective expulsions is intimately linked to it. ${ }^{16}$ The UN Committee Against Torture ('UN CAT') considers it part of the principle of non-refoulement, inasmuch as it guarantees and enables its applicability in practice. ${ }^{17}$ Indeed, the prohibition of collective expulsion is the proce-

9 ECtHR, Judgment (GC), 15 December 2016, Khlaifia and Others $v$ Italy, Application No. 16483/12; ECtHR, Judgment, 25 June 2020, Moustahi v France, Application No. 9347/14.

10 ECtHR, Judgment, 24 March 2020, Asady and Others $v$ Slovakia, Application No. 24917/15; ECtHR, Judgement, 23 July 2020, M.K. and others $v$ Poland, Application No. 40503/17; ECtHR, Judgment, 8 July 2021, D.A. and others $v$ Poland, Application No. 51246/17.

11 ECtHR, Judgment, 21 October 2014, Sharifi and Others $v$ Italy and Greece, Application No. 16643/09.

12 ECtHR, Judgment (GC), 13 February 2020, N.D. and N.T. $v$ Spain, Application Nos. 8675/15 and 8697/15; ECtHR, Judgment, 8 July 2021, Shahzad v Hungary, Application No. 12625/17.

13 ECtHR, Judgment (GC), 23 February 2012, Hirsi Jamaa and Others v Italy, Application No. 27765/09.

14 Article 4 Protocol 4 ECHR; Article 19(1) of the EU Charter on Fundamental Rights; Article 12(5) of the African Charter for Human and Peoples' Rights; Article 22(9) of the American Convention on Human Rights; Article 26(2) of the Arab Charter on Human Rights; Article 22(1) of the International Convention on the Rights of Migrant Workers.

15 See for example UN General Assembly, International Law Commission, Third report on the expulsion of aliens. By Mr. Maurice Kamto, Special Rapporteur, 19 April 2007, UN Doc. A/CN.4/581, para. 115.

16 See also Riemers, The Probibition of Collective Expulsion in Public International Law (2020), $248 \mathrm{ff}$.

17 CAT, General Comment No. 4 (2017) on the implementation of article 3 of the Convention in the context of article 22, 9 February 2018, UN Doc. CAT/C/GC/4, paras. 13 and 18; UN High Commissioner on Refugees ['UNHCR'], Submission by the Office of the United Nations High Commissioner for Refugees in the cases of N.D. and N.T. $v$ Spain (Appl. Nos 8675/15 and 8697/15) before the European Court of Human Rights, 15 November 2015, https://www.refworld.org/cgi-bin/texis/vtx/rw 
dural guarantee which allows all national and international protection mechanisms - including but not limited to those under refugee law ${ }^{18}-$ to be claimed, considered and ultimately implemented.

\section{B. The Prohibition of Collective Expulsion and Strasbourg: A Basic Definition}

The prohibition of collective expulsion is drafted as an absolute prohibition in protocol 4 ECHR. ${ }^{19}$ In this section, we will look at how the Court has defined 'expulsion' (I), 'alien' (II) and 'collective' and which safeguards arise from the prohibition (III).

\section{Expulsion}

The first definition of 'expulsion' in the context of article 4 protocol 4 ECHR was given by the Commission as, 'any measure [...] compelling aliens $[\ldots]$ to leave the country. ${ }^{20}$ This definition will subsequently be taken over by the Court. ${ }^{21}$

main?docid=59d3a81f4, para. 11; see also UNHCR's oral submissions during the the ECtHR's Grand Chamber in N.D. and N.T. vs. Spain, https://www.echr.coe.in t/Pages $/$ home.aspx? $\mathrm{p}=$ hearings $\& \mathrm{w}=867515 \_26092018 \&$ language $=$ lang $\& \mathrm{c}=\& \mathrm{py}=20$ 18.

18 UN Office of the High Commissioner for Human Rights ['OHCHR'], OHCHR intervention before the European Court of Human Rights in the case of N.D. and N.T v Spain, 9 October 2015, para. 19, https://www.refworld.org/type,AMICUS,OHCH R,ESP, 57a876f34,0.html.

19 This is confirmed in Council of Europe, Collected Edition of the "Travaux Préparatoires" of Protocol No. 4 (1976), 428: 'The Working Party was also unanimous regarding the absolute prohibition of collective expulsion.', www.echr.coe.int/Lib rary/DIGDOC/Travaux/ECHRTravaux-P4-BIL2907919.pdf.

20 European Commission of Human Rights, Decision, 3 October 1975, Becker $v$ Denmark, Application No. 7011/75 was the third decision ever taken in an article 4 protocol 4 ECHR case.

21 ECtHR, Judgment, 23 February 1999, Andric v Sweden, Application No. 45917/99 is the first claim under article 4 protocol 4 ECHR considered by the Court. ECtHR, Judgment, 5 February 2002, Čonka v Belgium, Application No. 51564/99 is the first case considered on merits by the Court under article 4 protocol 4 , resulting in a finding of violation. ECtHR, Judgment, 20 September 2007, Sultani $v$ France, Application No. 45223/05 is the second case considered on the merits but where the Court concluded there had been no violation. 
The definition was further developed in the first case to reach the Grand Chamber regarding article 4 protocol 4 ECHR, namely Hirsi Jamaa and Others $v$. Italy. ${ }^{22}$ In this case, a group of refugees and migrants was intercepted on the high sea by Italian officials. They were made to board an Italian military ship, but instead of being transferred to Italy and/or given access to the Italian asylum procedure, they were handed over to Libyan officials who took them back to Libya. The Grand Chamber referred back to the travaux préparatoires, ${ }^{23}$ where the drafters of the $4^{\text {th }}$ protocol explained that 'expulsion' should be interpreted, 'in the generic meaning, in current use (to drive away from a place). ${ }^{24}$ Though this definition was provided by the drafters in relation to the prohibition of expulsion of nationals (article 3 protocol 4 ECHR), the Grand Chamber concluded that it ought to be understood as applying to all articles of protocol 4 ECHR. ${ }^{25}$

Thus, in Hirsi Jamaa and Others v. Italy, the Grand Chamber established that a collective expulsion, or a 'driving away', could occur not only from a country or a territory, but from anywhere where a state's jurisdiction was confirmed. ${ }^{26}$ The Grand Chamber pointed out that its reasoning was in line with its previous jurisprudence on jurisdiction. ${ }^{27}$ The Grand Chamber nonetheless addressed explicitly the implications of the applicability of the prohibition of collective expulsions on the high sea. In doing so, it relied on the interpretative principles of good faith and effectiveness. The Court considered that, in a context where state parties increasingly carry out border control operations outside of their territory, these principles called for 'expulsion' to include an act of driving away from the high sea. ${ }^{28}$

This definition was confirmed by all subsequent Grand Chamber judgments on article 4 protocol 4 ECHR. ${ }^{29}$ In a number of cases, the Court has

22 ECtHR, Judgment (GC), 23 February 2012, Hirsi Jamaa and Others v Italy, Application No. 27765/09.

23 Council of Europe, Collected Edition of the "Travaux Préparatoires" of Protocol No. 4 (1976).

24 ECtHR, Judgment (GC), 23 February 2012, Hirsi Jamaa and Others v Italy, Application No. 27765/09, para. 174.

25 Ibid.

26 Id., para. 172 ff. See also Riemers: The Prohibition of Collective Expulsion in Public International Law (2020), 81.

27 ECtHR, Judgment (GC), 23 February 2012, Hirsi Jamaa and Others v Italy, Application No. 27765/09, para. $176 \mathrm{ff}$.

$28 I d$., para. $171 \mathrm{ff}$.

29 See for example ECtHR, Judgment (GC), 15 December 2016, Khlaifia and Others $v$ Italy, Application No. 16483/12, para. 243; ECtHR, Judgment (GC), 13 February 2020, N.D. and N.T. $v$ Spain, Application Nos. 8675/15 and 8697/15, para. 137. 
reiterated that the formal name attributed by the state party to the act of driving away is irrelevant. ${ }^{30}$ Thus, whether the act is labelled by national authorities as an expulsion, a removal, a return, a refusal of entry, ${ }^{31}$ a denial of admission ${ }^{32}$ or a rescue operation, ${ }^{33}$ it will still constitute an expulsion for the purposes of article 4 protocol 4 ECHR. ${ }^{34}$

Finally, in establishing whether an expulsion occurred in cases where no procedure or process whatsoever occurred and the state party denies the occurrence of the expulsion, the Court defined a specific evidentiary threshold. In N.D. and N.T v. Spain, the Grand Chamber confirmed that for disputed summary expulsions, the burden of proof shifts once the applicants provide prima facie evidence of their account. ${ }^{35}$ On the facts of that particular case, the Grand Chamber considered that such prima facie evidence existed given (i) that the applicants' account as to their overall individual circumstances was coherent, (ii) that the state party had not

30 ECtHR, Judgment (GC), 13 February 2020, N.D. and N.T. $v$ Spain, Application Nos. 8675/15 and 8697/15, para. 137.

31 Ibid.; ECtHR, Judgment (GC), 15 December 2016, Khlaifia and Others v Italy, Application No. 16483/12, paras. 226 and 243; ECtHR, Judgment (GC), 23 February 2012, Hirsi Jamaa and Others $v$ Italy, Application No. 27765/09.

32 As was argued in ECtHR, Judgment, 21 October 2014, Sharifi and Others $v$ Italy and Greece, Application No. 16643/09, para. 193.

33 As was argued in ECtHR, Judgment (GC), 23 February 2012, Hirsi Jamaa and Others $v$ Italy, Application No. 27765/09, para. 79.

34 As noted by the Grand Chamber in ECtHR, Judgment (GC), 13 February 2020, N.D. and N.T. $v$ Spain, Application Nos. $8675 / 15$ and 8697/15, para. 175 f., this is in line with the International Law Commission ('ILC')'s Draft articles on the expulsion of aliens. Indeed, though article 2 of the draft articles excludes 'non-admission' from the definition of 'expulsion,' commentary (5) clarifies that, 'the measures taken by a State to compel an alien already present in its territory, even if unlawfully present, to leave it are covered by the concept of "expulsion" as defined in draft article 2, subparagraph (a) [emphasis added].' See ILC, Draft articles on the expulsion of aliens, with commentaries (2014), https://legal.un.org/ilc/texts /instruments/english/commentaries/9_12_2014.pdf. Thus the notion of 'admission' and 'non-admission' under the draft articles differ significantly from that of 'admission' and 'non-admission' under the Schengen Border Code, as referred to in relation to the 'Entry conditions for third country nationals' (article 6(1)(c)) and to 'Border checks on persons' (article 8(3)(v)).

35 ECtHR, Judgment (GC), 13 February 2020, N.D. and N.T. $v$ Spain, Application Nos. $8675 / 15$ and $8697 / 15$, para. 85 . In doing so, the Grand Chamber relied on a line of jurisprudence, quoting ECtHR, Judgment (GC), 13 December 2012, El Masri v the former Yugoslav Republic of Macedonia, Application No. 39630/09 and ECtHR, Judgment (GC), 23 June 2016, Baka v Hungary, Application No. 20261/12. 
denied the occurrence of a collective expulsion on the relevant date and (iii) that such practice had been entrenched in national law. ${ }^{36}$

\section{Collective}

The term 'collective' under article 4 protocol 4 ECHR does not call for a quantitative or characterising approach, ${ }^{37}$ but rather a procedural one. Indeed when the drafters first included the prohibition in their draft article, they added a paragraph reading, 'Decisions of expulsion shall only be taken in individual cases; collective expulsion shall not, in any circumstances, be permitted. ${ }^{38}$ Though the final text simply reads, 'collective expulsion of aliens is prohibited', both the Commission and the Court stayed true to the procedural essence of the prohibition and defined as 'collective' any expulsion measure not taken on the basis of an individualised examination. ${ }^{39}$

The Grand Chamber in Hirsi Jamaa and Others v. Italy further specified the requirement of an individualised examination, requesting that the evidence shows 'the existence of sufficient guarantees ensuring that the

36 ECtHR, Judgment (GC), 13 February 2020, N.D. and N.T. $v$ Spain, Application Nos. $8675 / 15$ and $8697 / 15$, para. $86 \mathrm{ff}$.

37 Id., para. 194, where any quantitative or characteristic requirements were expressly excluded by the Court's Grand Chamber; see also ECtHR, Judgment, 25 June 2020, Moustahi v France, Application No. 9347/14, para. 129.

38 Council of Europe, Collected Edition of the "Travaux Préparatoires" of Protocol No. 4 (1976), 430, para. 56.

39 The Commission was first to define such an individual examination in European Commission of Human Rights, Decision, 3 October 1975, Becker v Denmark, Application No. 7011/75 as one which formed the basis of and preceded the expulsion measure ('a measure taken after and on the basis of...') and was 'a reasonable and objective examination of the particular cases of each individual alien of the group.' The Court took this approach in its first decision on article 4 protocol 4 ECHR in ECtHR, Judgment, 23 February 1999, Andric v. Sweden, Application No. 45917/99, para.1, where it defined a collective expulsion measure as one not 'taken on the basis of a reasonable and objective examination of the particular case of each individual alien of the group.' This line of jurisprudence was subsequently confirmed. See, mutatis mutandi, ECtHR, Judgment, 5 February 2002, Conka v Belgium, Application No. 51564/99, para. 59; ECtHR, Judgment (GC), 15 December 2016, Khlaifia and Others v Italy, Application No. 16483/12; ECtHR, Judgment (GC), 13 February 2020, N.D. and N.T. $v$ Spain, Application Nos. $8675 / 15$ and $8697 / 15$, para. 193. Interestingly, the Grand Chamber in ECtHR, Judgment (GC), 23 February 2012, Hirsi Jamaa and Others v Italy, Application No. 27765/09, para. 166, took the definition provided in Becker v Denmark with the inclusion of 'taken after' as a requirement. 
individual circumstances of each of those concerned were actually the subject of a detailed examination. ${ }^{40}$ This definition was subsequently applied in chamber judgments. ${ }^{41}$ However, the Grand Chamber in Kblaifia and Others $v$. Italy will shift its approach, by ruling out the necessity for an individual interview and defining a much less protective two-fold test. In that judgment, the Grand Chamber deemed it enough for the non-national to have 'a genuine and effective possibility of submitting arguments against his or her expulsion' and when such opportunity is deemed to have existed and arguments where raised, for those arguments to be 'examined in an appropriate manner by the authorities of the respondent State. ${ }^{32}$

It may be tempting to see in this approach sheer common-sense and pragmatism. Yet this reasoning disguises a crucial change: it is no longer for state parties to prove that they provided enough safeguards for an individualised examination to occur, but for the applicants to prove that they did not have any opportunity to oppose their expulsion. In light of the complete imbalance of power at borders between state parties and (here detained) applicants, in practice this shift is likely to translate into a merely theoretical and illusory existence of the safeguards provided for by article 4 protocol 4 ECHR. ${ }^{43}$ In fact, in Khlaifia and Others $v$. Italy the Grand Chamber considered that identification processes were sufficient, though the state party was unable to produce any document proving that the identity checks had actually taken place - let alone evidence as to whether they met the safeguards defined under article 4 protocol 4 ECHR. ${ }^{44}$ The Grand Chamber even advanced that another such opportunity to raise arguments against the expulsion had existed when the applicants had met

40 ECtHR, Judgment (GC), 23 February 2012, Hirsi Jamaa and Others $v$ Italy, Application No. 27765/09, para. 185.

41 ECtHR, Judgment, 21 October 2014, Sharifi and Others $v$ Italy and Greece, Application No. 16643/09, para. 214.

42 ECtHR, Judgment (GC), 15 December 2016, Kblaifia and Others $v$ Italy, Application No. 16483/12, para. 248. See also Gericke: 'Zwischen effektivem Menschenrechtsschutz und Realpolitik. Die jüngere Rechtsprechung des EGMR zum Rechtsschutz an den EU-Außengrenzen' (2020), 12/2020, Asylmagazin, Zeitschrift für Flüchtlings-und Migrationsrecht, 14 (15); Riemers: The Prohibition of Collective Expulsion in Public International Law (2020), $171 \mathrm{f}$. and 190.

43 Id., Partly Dissenting Opinion of Judge Serghides, para. 12.

44 The applicants had submitted that the identity checks had happened with no translation or legal advice, whilst the state party maintained that translators were present. Id., para. $245 \mathrm{ff}$. 
with Tunisian diplomatic officials before being deported back to Tunisia, their origin country. ${ }^{45}$

Ultimately, the Grand Chamber in Khlaifia and Others $v$. Italy was of the view that in any event the applicants had no arguments to raise against their expulsion. ${ }^{46}$ Yet one could argue that determining the applicability of a procedural safeguard by assessing its usefulness ex post facto contradicts the raison d'etre of procedural safeguards, which is to ensure that sufficient guarantees are in place for a certain process - here an individualised examination - to take place. ${ }^{47}$

\section{Alien}

The provision prohibiting collective expulsions was drafted very broadly by the all-encompassing term of 'aliens' with no distinction. In order to dissipate all doubts, the Committee of Experts drafting the provision further highlighted,

The term 'aliens' shall here be taken to mean all those who have no actual right to nationality in a State, whether they are passing through a country or reside or are domiciled in it, whether they are refugees or entered the country on their own initiative, or whether they are stateless or possess another nationality. The collective expulsion of nationals is prohibited under article 3 [protocol 4 ECHR] ${ }^{48}$

This last sentence is a final testament as to the Committee's concern that everyone - nationals, non-nationals, stateless persons, refugees, nonrefugees - should be protected from collective expulsions.

The Committee's definition is remarkable in its intention to clarify that such protection should not depend on status (residency, nationality or refugee status) or on the way of entry ('on their own initiative') or on the

45 ECtHR, Judgment (GC), 15 December 2016, Khlaifia and Others $v$ Italy, Application No. 16483/12, para. 250; Gericke: 'Zwischen effektivem Menschenrechtsschutz und Realpolitik. Die jüngere Rechtsprechung des EGMR zum Rechtsschutz an den EU-Außengrenzen' (2020), 12/2020, Asylmagazin, Zeitschrift für Flüchtlings-und Migrationsrecht, 14 (15 f.)

46 Id., para. 253.

47 In fact in more recent judgments, the Court has gone back to the original definition of collective as a lack of individual assessment. See ECtHR, Judgment, 8 July 2021, Shahzad v Hungary, Application No. 12625/17, para. 58.

48 Council of Europe, Collected Edition of the "Travaux Préparatoires" of Protocol No. 4 (1976), 505, para. 34. 
reasons of one's presence in a territory ('to seek refuge or not'). The travaux préparatoires reveal that in the Committee's eyes, this all-encompassing absolute prohibition came as a firm limit to state parties' acknowledged discretion to expel (residing) non-nationals. ${ }^{49}$

Though in its jurisprudence the Court has confirmed such a broad scope, ${ }^{50}$ in its latest judgment, the Grand Chamber drew much from article $3 \mathrm{ECHR}$ in its analysis as to the applicability of article 4 protocol 4 ECHR, thus blurring the line between the two. ${ }^{51}$ In practice, the Court has not yet found a violation of article 4 protocol 4 ECHR in cases where it considered that there was no substantial protection need and/or no related claim under article 3 ECHR. ${ }^{52}$ Arguably, such an approach contradicts the explicit intention of the drafters and effectively completely abrogates the safeguards provided for by article 4 protocol 4 ECHR. Indeed, as will be addressed in $(\mathrm{C})$, article 3 ECHR provides more extensive procedural and substantive safeguards against expulsions, especially if also combined with article 13 ECHR. Thus, if only applied to cases also presenting a claim under article $3 \mathrm{ECHR}$, article 4 protocol 4 ECHR becomes utterly superfluous. ${ }^{53}$

49 In the same section, the Committee explains that the initial provision drafted by the Assembly, which would have limited the grounds on which non-nationals could be expelled, was completely abandoned, as 'only the State concerned should be competent [...] to judge of the reasons which, applying its internal law, could motivate expulsion and that such judgement should not be subject to the bodies provided for by the Convention.' Council of Europe, Collected Edition of the "Travaux Préparatoires" of Protocol No. 4 (1976), 506, para. 36.

50 ECtHR, Judgment (GC), 13 February 2020, N.D. and N.T. $v$ Spain, Application Nos. 8675/15 and 8697/15, para. 185 ff., where the Grand Chamber notes that 'expulsion' means 'any forcible removal of an alien from a State's territory, irrespective of the lawfulness of the person's stay, the length of time he or she has spent in the territory, the location in which he or she was apprehended, his or her status as a migrant or an asylum-seeker and his or her conduct when crossing the border.'

51 Id., in particular paras. $184 \mathrm{ff}$. and $198 \mathrm{f}$.

52 Thus, the only two cases where there was no standing claim under article 3 ECHR, the Court concluded that there was no violation of article 4 protocol 4 ECHR. See ECtHR, Judgment (GC), 15 December 2016, Khlaifia and Others $v$ Italy, Application No. 16483/12 and ECtHR, Judgment (GC), 13 February 2020, N.D. and N.T. $v$ Spain, Application Nos. 8675/15 and 8697/15.

53 This was confirmed by the Court in ECtHR, Judgment, 20 July 2021, D. v Bulgaria, Application No. 29447/17, para. 139. 


\section{The 'Own Culpable Conduct' Exception}

In N.D. and N.T. v. Spain, the Grand Chamber defined a new exception ${ }^{54}$ to the prohibition of collective expulsions under article 4 protocol 4 ECHR. It found that in certain circumstances, a collective expulsion will not be in violation of article 4 protocol 4 ECHR.

This exception is to be considered in a three-fold step. ${ }^{55}$ First it applies in certain situations as defined in the judgment (1). Second, in those cases, the Court will assess whether the state party, 'provided genuine and

54 In ECtHR, Judgment (GC), 13 February 2020, N.D. and N.T. v Spain, para. 200, the Court claimed to ground this new exception on 'well-established case-law'. This qualification was strongly questioned by a number of legal scholars, as the jurisprudence on this point is limited to two admissibility decisions, namely ECtHR, Decision, 16 June 2005, Berisha and Haljiti v the former Yugoslav Republic of Macedonia, Application No. 18670/03 and in ECtHR, Decision, 1 February 2011, Dritsas and Others $v$ Italy, Application No. 2344/02. These cases have factually little in common between them as to what was deemed to constitute 'own culpable conduct'. Moreover, the extension of 'own culpable conduct' from acts of the applicants which had impeded attempts by the state party to examine cases individually (in the previously mentioned cases) to behaviour generally judged by the Court as justifying stripping applicants from their rights under article 4 protocol 4 ECHR (in N.D. and N.T. v. Spain) was also heavily criticised. See for example Pichl and Schmalz, "Unlawful" may not mean rightless', Verfassungsblog, 14 February, https://verfassungsblog.de/unlawful-may-not-mean-rightl ess/; Riemers: The Prohibition of Collective Expulsion in Public International Law (2020), 72; Ciliberto: 'A Brand-New Exclusionary Clause to the Prohibition of Collective Expulsion of Aliens: The Applicant's Own Conduct in N.D. and N.T. $v$ Spain' (2021) 21 Hum. Rights Law Rev., 203 (210). This position of the Court was also strongly condemned by ECtHR judge Pinto de Albuquerque in ECtHR, Judgment (GC), 21 January 2021, Georgia v Russia (II), Application No. 38263/08, Partly Dissenting Opinion of the Judge Pinto de Albuquerque, para. 19, 'The fallacy of the Court's line of argument is even more patent when it is stretched ad absurdum to deny the right of access to human rights to criminals or other "disruptive" people, whatever that might mean.'

55 ECtHR, Judgment (GC), 13 February 2020, N.D. and N.T. v Spain, Application Nos. 8675/15 and 8697/15, para. 201; ECtHR, Judgment, 8 July 2021, Shahzad $v$ Hungary, Application No. 12625/17, para. 59.

Elsewhere the test is defined as two-fold, with a precondition of applicability (which is the first step in the present article). See Gericke: 'Zwischen effektivem Menschenrechtsschutz und Realpolitik. Die jüngere Rechtsprechung des EGMR zum Rechtsschutz an den EU-Außengrenzen' (2020), 12/2020, Asylmagazin, Zeitschrift für Flüchtlings-und Migrationsrecht, 14 (19); Ciliberto: 'A Brand-New Exclusionary Clause to the Prohibition of Collective Expulsion of Aliens: The Applicant's Own Conduct in N.D. and N.T. $v$ Spain' (2021) 21 Hum. Rights Law Rev., 203 (211 ff.). 
effective access to means of legal entry, in particular border procedures.' Third, if such was the case, the Court will consider whether there were cogent reasons for the applicants not to use such means of legal entry. In light of their inter-connectedness, the second and third step will be considered together here (2). The final section will assess the impact of this new exception on the Court's approach to article 4 protocol 4 ECHR (3).

\section{Conditions of Applicability}

In N.D. and N.T. v. Spain, the Grand Chamber stated that the exception applied when applicants, 'cross a land border in an unauthorised manner, deliberately take advantage of their large numbers and use force, is such as to create a clearly disruptive situation which is difficult to control and endangers public safety. ${ }^{56}$

Thus, the applicability of the 'own culpable conduct' exception may be limited to irregular crossings of land borders. Many of the elements constituting the exception's applicability requirements remain to be clarified. First the expression 'large numbers' is unclear. The use elsewhere in the judgment of the term 'en masse' 57 suggests the need for a rather significant number of persons. In N.D. and N.T. v. Spain, the Court recorded that the group was of approximately 600 individuals..$^{58}$

Second, the Court refers to a deliberate 'use of force' several times in the judgment ${ }^{59}$ without defining the content of the expression. On the particular facts of the case, the Court described a 'storming' of the border fence ${ }^{60}$ and it found the requirement to be fulfilled. However, the terminology of 'use of force' is traditionally used to depict the non-consensual and violent administration of force onto a person. In fact the term appears once only in the Convention, in relation to article 2 ECHR and the right to life. ${ }^{61}$ In the Court's guides on its jurisprudence, the term exclusively appears

56 Id., para. 201.

57 Id., para. 166.

$58 I d$., para. 24.

59 Id., paras. 201, $210 \mathrm{f}$. and 231.

$60 I d$., paras. 227 and 231.

61 Article 2(2) ECHR, 'Deprivation of life shall not be regarded as inflicted in contravention of this Article when it results from the use of force which is no more than absolutely necessary: (a) in defence of any person from unlawful violence; (b) in order to effect a lawful arrest or to prevent the escape of a person lawfully detained; (c) in action lawfully taken for the purpose of quelling a riot or insurrection.' 
in relation to the use of force by law-enforcement officers or in armed conflicts. ${ }^{62}$ In N.D. and N.T. v. Spain, the judgment does not mention that the two applicants were violent towards other persons. It seems to be the act of climbing a border fence which was labelled as 'use of force'. A stricter definition has been used by the Court since, when in Shabzad $v$ Hungary, the Court discarded the applicability of the 'own culpable conduct' exception on the ground that there was no indication of use of force or resistance by the applicant or any other men, as these had followed the orders of the officers. ${ }^{63}$

Third, the use by the Court of the word 'deliberately' suggests that an intention is required, though it is unclear whether the intention is only to 'take advantage of large numbers', or also to use force, or even to 'create a clearly disruptive situation which is difficult to control and endangers public safety.' In N.D. and N.T. v. Spain, the individual intentions of the applicants were not assessed by the Court, as pointed out by former ECtHR judge Pinto de Albuquerque,

The suggested rationale of the Court is one of guilt by association, whereby all Africans climbing the border fences in Melilla act in the same manner, share the same intention and are in the same personal situation. In N.D. and N.T. v. Spain, the specific intentions of the applicants to disrupt and endanger public safety were never established and no evidence was ever put forward regarding any concrete violent acts committed by them or any other person crossing on that day. When reading the judgment, one gets the impression that the principle of individual responsibility has been completely obfuscated. ${ }^{64}$

62 Examples include the forceful taking of someone into custody: ECtHR, Guide on Article 13 of the European Convention on Human Rights, 30 April 2020, https:/ /www.echr.coe.int/Documents/Guide_Art_13_ENG.pdf, para. 99; the infliction of physical harm: ECtHR, Guide on Article 2 of the European Convention on Human Rights, 31 August 2020, https://www.echr.coe.int/Documents/Guide_ Art_2_ENG.pdf, para. 4; killings: ECtHR, Guide on Article 13 of the European Convention on Human Rights, 30 April 2020, https:/www.echr.coe.int/Docume nts/Guide_Art_13_ENG.pdf, para. 86; the use of high-pressure water and teargas and driving into a crowd with armoured vehicles: ECtHR, Guide on Article 11 of the European Convention on Human Rights, 31 August 2020, https://www.echr.c oe.int/Documents/Guide_Art_11_ENG.pdf, para. 82.

63 ECtHR, Judgment, 8 July 2021, Shahzad v Hungary, Application No. 12625/17, para. 61.

64 ECtHR, Judgment (GC), 21 January 2021, Georgia v Russia (II), Application No. 38263/08, Partly Dissenting Opinion of the Judge Pinto de Albuquerque, para. 20. 


\section{Genuine and Effective Access to Means of Legal Entry and Cogent Reasons}

This section analyses the second and third applicability requirements of the 'own culpable conduct' exception. In N.D. and N.T. v. Spain, the Grand Chamber found that genuine and effective access to means of legal entry existed, namely the possibility to claim asylum at border points and the possibility to apply for humanitarian visas at embassies and consular missions. ${ }^{65}$

Though the Grand Chamber did not spell out a definition in N.D. and N.T. $v$. Spain, jurisprudential definitions of 'genuine and effective' (1) and of 'effective' (2) have already been developed in the broader context of access to rights.

\section{1. 'Genuine and Effective' in the Court's Jurisprudence on Access to Rights}

The term 'genuine and effective' was introduced by the Grand Chamber in its assessment of claims under article 4 protocol 4 ECHR in Kblaifia and Others $v$. Italy ${ }^{66}$ and used again in N.D. and N.T. v. Spain ${ }^{67}$ The term has

65 ECtHR, Judgment (GC), 13 February 2020, N.D. and N.T. $v$ Spain, Application Nos. $8675 / 15$ and $8697 / 15$, para. 212 . This factual finding was unanimously criticised by commentators. See Pichl and Schmalz, "Unlawful" may not mean rightless', Verfassungsblog, 14 February, https://verfassungsblog.de/unlawful-m ay-not-mean-rightless/; Oviedo Moreno, 'A Painful Slap from the ECtHR and an Urgent Opportuniy for Spain' Verfassungsblog, 14 February 2020, https://ver fassungsblog.de/a-painful-slap-from-the-ecthr-and-an-urgent-opportunity-for-s pain/; Lübbe, 'The Elephant in the Room', Verfassungsblog, 19 February 2020, https://verfassungsblog.de/the-elephant-in-the-room/; Thym, 'A Restrictionist Revolution?', Verfassungsblog, 17 February 2020, https://verfassungsblog.de/a-rest rictionist-revolution/; Papageorgopoulos, 'N.D. and N.T. v. Spain: do hot returns require cold decision-making?', EDAL - European Database of Asylum Law, 28 February 2020, https://www.asylumlawdatabase.eu/en/journal/nd-and-nt-v-spain -do-hot-returns-require-cold-decision-making. The finding was even qualified as 'chimerical' by the Spanish judges association Juezas y Jueces para la Democracia. See Juezas y Jueces para la Democracia, Comunicado de JJpD acerca de la decisión del TEDH sobre las devoluciones en caliente: EUROPA SE BLINDA, 14 February 2020, http://www.juecesdemocracia.es/2020/02/14/comunicado-jjpd-acerca-la-decision-d el-tedh-las-devoluciones-caliente-europa-se-blinda/.

66 ECtHR, Judgment (GC), 15 December 2016, Khlaifia and Others v Italy, Application No. 16483/12, para. 248.

67 ECtHR, Judgment (GC), 13 February 2020, N.D. and N.T. v Spain, Application Nos. 8675/15 and 8697/15, para. 198. 
not been defined by the Court. ${ }^{68}$ In attempting to understand its meaning, this section will consider its use and content in relation to other articles of the ECHR and its protocols.

The term initially stems from the Court's assessment of states' obligations under article 6 ECHR. ${ }^{69}$ In that context, the Court has traditionally opposed 'genuine and effective' to a 'possibility [which] seems to be rather hypothetical. ${ }^{70}$ Thus, in considering whether there was a 'genuine and effective' access to a procedure in the context of article 6 ECHR, the Court assesses whether an applicant has 'a realistic opportunity' to engage in proceedings 'in a concrete and effective way. ${ }^{71}$

Importantly, the obligation to ensure genuine and effective access entails a proactive position of the state - including an obligation of due

68 The term was further used by the Court in ECtHR, Judgement, 23 July 2020, M.K. and others $v$ Poland, Application No. 40503/17, para. 203 and in ECtHR, Judgment, 24 March 2020, Asady and Others v Slovakia, Application No. 24917/15, para. 65 , but no definition was provided.

69 It is first used in a partly dissenting opinion in ECtHR, Judgment (GC), 16 September 1996, Süssmann v Germany, Application No. 20024/92, Partly Dissenting Opinion of Judges Jambrek and Pettiti, para. 10: 'First, any modern Constitution is based upon respect of the rule of law and of the fundamental human rights and freedoms, while the principles of fair and speedy trial are prerequisites for their genuine and effective respect.' The term was then first used by the Court in a judgment in relation to states' obligations to secure 'the genuine and effective enjoyment of the rights guaranteed under article 6 ECHR' in ECtHR, Judgment, 18 December 2001, R.D. v Poland, Application No. 29692/96, para. 44.

70 ECtHR, Judgment, 13 March 2007, Laskowska v Poland, Application No. 77765/01, para. 60; also in relation to article $10 \mathrm{ECHR}$, see for example ECtHR, Judgement, 24 April 2018, Fatih Tas v Turkey (No. 4), Application No. 51511/08, para. 33.

71 See for example ECtHR, Judgment, 18 December 2001, R.D. v. Poland, Application No. 29692/96, para. 51; ECtHR, Judgment, 22 March 2007, Staroszczyk $v$ Poland, Application No. 59519/00, para. 138; ECtHR, Judgment, 27 June 2006, Tabor v. Poland, Application No. 12825/02, para. 43. 
diligence $^{72}$ - rather than a mere negative obligation not to interfere. ${ }^{73}$ Furthermore, in considering the extent of the applicant's responsibility for any obstacles encountered in accessing a procedure in a concrete and effective way, the Court considers what is to be reasonably and justifiably expected from them. ${ }^{74}$

The approach of the Grand Chamber in N.D. and N.T. v. Spain differs greatly. In relation to the 'own culpable conduct' exception, obstacles which may completely hinder access to the relevant means of legal entry are disregarded if not deemed to be the responsibility of the respondent state. ${ }^{75}$ Also, the Grand Chamber did not include any assessment as to whether it would be reasonable to expect applicants to attempt to use the identified means of legal entry. ${ }^{76}$

72 See for example ECtHR, Judgment, 17 June 2008, Bobrowski v Poland, Application No. 64916/01, para. 47: 'In discharging that obligation of fairness, the State must, moreover, display diligence so as to secure to those persons the genuine and effective enjoyment of the rights guaranteed under Article 6'; ECtHR, Judgment, 13 January 2009, Miroslaw Orzechowsi v Poland, Application No. 13526/07; ECtHR, Judgment, 19 May 2009, Antonicelli v Poland, Application No. 2815/05; ECtHR, Judgment, 17 July 2012, Muscat $v$ Malta, Application No. 24197/10; ECtHR, Judgment, 26 July 2018, Bartaia v Georgia, Application No. 10978/06, para. 34; ECtHR, Judgment, 04 April 2019, Kunert v Poland, Application No. 8981/14.

73 In relation to access to rights under article 11 ECHR, see ECtHR, Judgment, 20 October 2005, Ouranio Toxo and others $v$ Greece, Application No. 74989/01, para. 37; ECtHR, Judgment, 16 July 2019, Zhdanov and Others $v$ Russia, Application No. $12200 / 08$, para. 162 . In relation to access to rights under article $10 \mathrm{ECHR}$, see ECtHR, Judgment (GC), 12 September 2011, Palomo Sanchez and Others v Spain, Application No. 28955/06.

74 ECtHR, Judgment, 04 April 2019, Kunert v Poland, Application No. 8981/14, para. 36; ECtHR, Judgment, 03 July 2012, Siwiec v Poland, Application No. 28095/08, para. 52 f.; ECtHR, Judgment, 26 May 2016, Wieslaw Berecki v Poland, Application No. 46366/12, para. 25.

75 ECtHR, Judgment (GC), 13 February 2020, N.D. and N.T. v Spain, Application Nos. 8675/15 and 8697/15, para. 201.

76 As noted by Ciliberto, similarly, the requirement to exhaust effective domestic remedies (addressed in the next section) does not need to be fulfilled when doing so would be 'dangerous or impossible'. See Ciliberto: 'A Brand-New Exclusionary Clause to the Prohibition of Collective Expulsion of Aliens: The Applicant's Own Conduct in N.D. and N.T. v Spain' (2021) 21 Hum. Rights Law Rev., 203 (216). 


\section{2. 'Effective' in the Court's Jurisprudence on Access to Rights before Domestic Courts}

The term 'effective' is also the subject of a well-established jurisprudence to assess whether the domestic legal system provides for effective access to the rights and safeguards enshrined within the ECHR. In that sense, such jurisprudence clarifies how the Court has defined what constitutes an effective access to rights. This jurisprudence is thus relevant to consider what constitutes effective access to means of legal entry. ${ }^{77}$

Effectiveness entails availability in law and in practice. ${ }^{78}$ To be available in law, a measure needs to have a sufficiently clear legal basis. ${ }^{79}$ Measures that are entirely discretionary cannot provide effective access. ${ }^{80}$ In assessing whether a measure is available in practice, the Court considers whether it has been successfully used in the past ${ }^{81}$ and whether it offers reasonable prospects of success. ${ }^{82}$ Whether obstacles from the availability of a remedy in practice fall under the responsibility of the respondent state is irrelevant. $^{83}$

Again, the approach of the Court in N.D. and N.T. v. Spain departs from this line of jurisprudence. First, in assessing the accessibility of asylum applications at border crossings, the Court dismissed the relevance of racial profiling by Moroccan authorities as none of the evidence 'suggest[ed] that the Spanish Government was in any way responsible for this state of affairs. ${ }^{94}$ Further the Grand Chamber concluded that the extremely

77 See also $i d ., 213 \mathrm{ff}$.

78 ECtHR, Judgment (GC), 6 January 2011, Paksas v Lituania, Application No. 34932/04, para. 75; ECtHR, Judgment (GC), 01 March 2006, Sejdovic v Italy, Application No. 56581/00, para. 45.

79 ECtHR, Judgment (GC), 8 June 2006, Sürmeli v Germany, Application No. 75529/01, para. $110 \mathrm{ff}$.

80 ECtHR, Judgment (GC), 26 October 2000, Hassan \& Tchaouch v Bulgaria, Application No. 30985/96, para. 100; ECtHR, Judgment, 12 May 2000, Khan v United Kingdom, Application No. 35394/97, para. 45 ff.

81 ECtHR, Judgment, 28 November 2006, Apostol v Georgia, Application No. 40765/02, para. 39.

82 ECtHR, Judgment (GC), 17 September 2009, Scoppola v Italy (no. 2), Application No. 10249/03, para. 71; ECtHR, Judgment, 18 January 2011, Mikolajova v Slovakia, Application No. 4479/03, para. 34.

83 As pointed out in Ciliberto: 'A Brand-New Exclusionary Clause to the Prohibition of Collective Expulsion of Aliens: The Applicant's Own Conduct in N.D. and N.T. v Spain' (2021) 21 Hum. Rights Law Rev., 203 (216).

84 ECtHR, Judgment (GC), 13 February 2020, N.D. and N.T. $v$ Spain, Application Nos. 8675/15 and 8697/1, para. 218. 
low rate of success as to access to the border point was of no relevance, ${ }^{85}$ despite it indicating extremely low prospects of success.

Moreover, in relation to the accessibility of humanitarian visas, the respondent state's evidence consisted of an internal letter from the ministry to ambassadors which, in light of an unclear legal situation, ${ }^{86}$ clarified that they held discretionary power to grant humanitarian visas. ${ }^{87}$ The Grand Chamber considered that this entirely discretionary measure mentioned in a non-public document fulfilled the 'genuine and effective' test. ${ }^{8}$

\section{Impact of the 'Own Culpable Conduct' Exception on the Applicability of Article 4 Protocol 4 ECHR at Borders}

As pointed out by commentators, ${ }^{89}$ this newly defined exception raises more questions than it provides answers. A few weeks after the publication of the Grand Chamber's judgement, Greek authorities were shooting refugees and migrants with rubber bullets and gas canisters to push them back into Turkey. ${ }^{90}$ These dramatic events painstakingly illustrated three points. First, unless all are identified and processed, it is impossible to know if a collective expulsion is also a refoulement or not. Second, the issue of access to rights by refugees and migrants at land borders will not disappear simply because a new legal exception is created to minimise - if not abrogate - state parties' obligations under article 4 protocol 4

85 Id., para. 213, where the Court grounds its finding that there was a genuine and effective access to border crossings on the registration of six applications 'at the Beni-Enzar border' from black African applicants over a period of eight months.

86 As pointed out by the Grand Chamber, Spanish refugee law practitioners (authors of the AIDA report referred to) considered this possibility to be inexistent. Id., para. 224.

87 Id., paras. 38 and 224.

88 Id., para. 227.

89 Markard, 'A Hole of Unclear Dimensions: Reading ND and NT v. Spain', 1 April 2020, https://eumigrationlawblog.eu/a-hole-of-unclear-dimensions-reading-nd-and -nt-v-spain/.

90 Christides et al., 'The Killing of a Migrant at the Greek-Turkish Border', SPIEGEL International, 8 May 2020, https:/www.spiegel.de/international/europe/greek-tur kish-border-the-killing-of-muhammad-gulzar-a-7652ff68-8959-4e0d-9101-a1841a94 4161. 
ECHR. Third, the judgment was read by governments as a carte blanche to forcefully push refugees and migrants back. ${ }^{91}$

Since the publication of the N.D. and N.T. $v$. Spain judgment, five further chamber judgements on article 4 protocol 4 ECHR have been issued by the Court. Four address the expulsions of persons seeking asylum at land border crossings, ${ }^{92}$ whilst one concerns the expulsions of children after a boat interception. ${ }^{93}$ In the first border crossing case, the applicants' claim was dismissed on evidentiary grounds. ${ }^{94}$ In the two remaining cases, violations of the prohibition of collective expulsions were found. ${ }^{95}$ In all of these judgments, N.D. and N.T. v. Spain was barely mentioned.

This could be explained by the fact that none of these cases concerns irregular land border crossings, confirming that the 'own culpable conduct' exception is truly limited to that particular type of unauthorised crossing. A further reason could be that the exception as defined by the Grand Chamber in N.D. and N.T. v. Spain is so intricate and unclear that it does not, in fact, provide much guidance as to how such cases should be assessed. Though the Grand Chamber in N.D. and N.T. v. Spain adopted a politically conservative approach and dismissed the claim, a legally rigorous application of that same exception could have led to the opposite outcome. Therefore, the position of the Court as to access to

91 Goldner Lang, 'Which Connection between the Greek Turkish Border, the Western Balkans Route and the ECtHR's judgment in ND and NT?' 4 September 2020, http://eumigrationlawblog.eu/2750-2/. It was pointed out that though article 4 protocol 4 ECHR is not applicable in the Greek context (because Greece has not ratified protocol 4), a link was immediately made in the political sphere between the Grand Chamber decision in N.D. and N.T. $v$ Spain and the situation at the Greek-Turkish border. See Gericke: 'Zwischen effektivem Menschenrechtsschutz und Realpolitik. Die jüngere Rechtsprechung des EGMR zum Rechtsschutz an den EU-Außengrenzen' (2020), 12/2020, Asylmagazin, Zeitschrift für Flüchtlings- und Migrationsrecht, 14 (19).

92 ECtHR, Judgment, 24 March 2020, Asady and Others $v$ Slovakia, Application No. 24917/15; ECtHR, Judgement, 23 July 2020, M.K. and others $v$ Poland, Application No. 40503/17; ECtHR, Judgment, 8 July 2021, Shahzad v Hungary, Application No. 12625/17; ECtHR, Judgment, 8 July 2021, D.A. and others $v$ Poland, Application No. 51246/17.

93 ECtHR, Judgment, 25 June 2020, Moustahi v France, Application No. 9347/14.

94 ECtHR, Judgment, 24 March 2020, Asady and Others v Slovakia, Application No. 24917/15.

95 ECtHR, Judgement, 23 July 2020, M.K. and others $v$ Poland, Application No. 40503/17; ECtHR, Judgment, 25 June 2020, Moustahi v France, Application No. 9347/14. 
rights under article 4 protocol 4 at land borders is still to be defined as the jurisprudence develops.

Practically, the judgment offers no guidance to border guards. Indeed, the 'own culpable conduct' test calls for complex assessments as to the individual circumstances of the applicants and their endeavours to enter a territory in an authorised manner. Thus an individualised examination is still necessary, arguably an examination more complex than if the exception did not apply. ${ }^{96}$ In reality border guards are likely to make sweeping assumptions of collective circumstances, which are equally unlikely to reach the Court for an ex post facto assessment half a decade later. ${ }^{97}$ In that sense, the judgment as it stands is an invitation to push refugees and migrants back. Further the jurisprudence of the Court is now no longer in line with international human rights law.

\section{The Prohibition of Collective Expulsions: A Comparative Conclusion}

\section{The Prohibition of Collective Expulsions within the ECHR Framework}

The prohibition of collective expulsions is one of the rights which one could invoke in relation to an expulsion. ${ }^{98}$ This section will outline the

96 Indeed, when article 4 protocol 4 ECHR calls for the identification of a person and an opportunity to challenge the expulsion, the 'own culpable conduct' exception requires a detailed questioning as to previous attempts to access means of legal entry, reasons why these were not used and an assessment as to whether these reasons are cogent or not. See also Gericke: 'Zwischen effektivem Menschenrechtsschutz und Realpolitik. Die jüngere Rechtsprechung des EGMR zum Rechtsschutz an den EU-Außengrenzen' (2020), 12/2020, Asylmagazin, Zeitschrift für Flüchtlings-und Migrationsrecht, 14 (19).

97 For a critical analysis of the Court's ex post facto assessment in article 4 protocol 4 ECHR cases, see Riemers, The Prohibition of Collective Expulsion in Public International Law (2020), $190 \mathrm{ff}$.

98 Hence article 1 protocol 7 ECHR is specifically applicable to non-nationals having obtained residency in the state party. Further articles 2 (right to life) and 8 (right to family life) can also be invoked to challenge expulsions. See for example ECtHR, Judgment (GC), 23 March 2016, F.G. v Sweden, Application No. 43611/11, for article 2 ECHR and ECtHR, Judgment (GC), 13 December 2012, De Souza Ribeiro v France, Application No. 22689/07, for article 8 ECHR. The Court even indicated that in some cases, expulsions could raise issues under article $6 \mathrm{ECHR}$ when the applicant would be facing 'flagrant denial of a fair trial' in ECtHR, Judgment (GC), 7 July 1989, Soering v United Kingdom, Application No. 14038/88, para. 113. 
safeguards provided by other articles under the ECHR and its protocols, with a focus on the most relevant ones, namely (1) the prohibition of torture and inhuman or degrading treatment under article 3 ECHR and (2) the right to an effective remedy under article 13 ECHR

\section{Article 3 ECHR and the Probibition of Torture and Inhuman or Degrading Treatment}

Where article 4 protocol 4 ECHR was drafted to apply to all non-nationals, article 3 ECHR only applies to those who face an imminent risk of torture, inhuman or degrading treatment directly or indirectly upon expulsion.

Though both article 3 and article 4 protocol 4 ECHR are framed in absolute terms, the safeguards afforded by article 3 ECHR are much more protective. Indeed, this provision prohibits state parties from knowingly surrendering a person to another state when there are substantial grounds to believe that the person runs a real risk of exposure to torture or inhuman or degrading treatment or punishment. ${ }^{99}$ The individual assessment required is thus better defined. In fact article 3 ECHR imposes an obligation on states to assess such risk on their own initiative when they ought to know of it, for example when information about a real and concrete risk of treatment in breach of article 3 ECHR is available from numerous public sources. ${ }^{100}$ Therefore, state parties cannot defend claims under article 3 ECHR by alleging that an applicant did not raise the risks which she would be imminently exposed to upon expulsion.

99 ECtHR, Judgment (GC), 7 July 1989, Soering $v$ United Kingdom, Application No. 14038/88; ECtHR, Judgment (GC), 20 March 1991, Cruz Varas and Others $v$ Sweden, Application No. 15576/89, para. 69 ff.; ECtHR, Judgment (GC), 28 February 2008, Saadi v Italy, Application No. 37201/06, para. $124 \mathrm{f}$.

100 See, mutatis mutandis, ECtHR, Judgment (GC), 15 November 1996, Chahal v United Kingdom, Application No. 22414/93, para. 104 f.; ECtHR, Judgment, 11 July 2000, Jabari v Turkey, Application No. 40035/98, para. 40 f.; ECtHR, Judgment (GC), 21 January 2011, M.S.S. $v$ Belgium and Greece, Application No. 30696/09, para. 359; ECtHR, Judgment (GC), 23 February 2012, Hirsi Jamaa and Others $v$ Italy, Application No. 27765/09, para.133; ECtHR, Judgment (GC), 21 November 2019, Ilias and Abmed v Hungary, Application No. 47287/15, para. 141. 


\section{Article 13 ECHR and the Right to an Effective Remedy}

The most significant difference between article 13 and article 4 protocol 4 ECHR is that, whilst the prohibition of collective expulsions can be claimed as a free-standing right, article 13 ECHR is an instrumental right which can only be claimed in connection with another ECHR right. ${ }^{101}$

When claimed in connection with article 3 ECHR - and unlike when claimed in connection with article 4 protocol 4 ECHR, ${ }^{102}$ article 13 ECHR requires from domestic remedies to have automatic suspensive effect. ${ }^{103}$ Further, in those cases article 13 ECHR affords the right to a close, rigorous and independent scrutiny of the claim by the authorities ${ }^{104}$ in a reason-

101 ECtHR, Guide on Article 13 of the European Convention on Human Rights, 31 August 2020, https://www.echr.coe.int/Documents/Guide_Art_13_ENG.pdf.

102 In ECtHR, Judgment (GC), 15 December 2016, Khlaifia and Others $v$ Italy, Application No. 16483/12, para. 279, the Grand Chamber reversed previous jurisprudence, following which for claims under article 13 in connection to article 4 protocol 4 ECHR, a remedy would not be effective against an expulsion if it did not carry automatic suspensive effect. See ECtHR, Judgment (GC), 13 December 2012, De Souza Ribeiro v France, Application No. 22689/07, para. 82; ECtHR, Judgment (GC), 23 February 2012, Hirsi Jamaa and Others $v$ Italy, Application No. 27765/09, para.199; ECtHR, Judgment, 5 February 2002, Conka v Belgium, Application No. 51564/99, para. $76 \mathrm{ff}$.

103 ECtHR, Judgment (GC), 15 December 2016, Khlaifia and Others v Italy, Application No. 16483/12, paras. 276 and 281; ECtHR, Judgment (GC), 13 December 2012, De Souza Ribeiro v France, Application No. 22689/07, para. 82; ECtHR, Judgment (GC), 23 February 2012, Hirsi Jamaa and Others $v$ Italy, Application No. 27765/09, paras. 199 ff.; ECtHR, Judgment, 5 February 2002, Conka v Belgium, Application No. 51564/99, para. 79 ff.; ECtHR, Judgment, 26 April 2007, Gebremedhin [Gaberamadhien] v France, Application No. 25389/05, paras. 58 and 66.

104 ECtHR, Judgment (GC), 23 February 2012, Hirsi Jamaa and Others $v$ Italy, Application No. 27765/09, para. 198; ECtHR, Judgment (GC), 13 December 2012, De Souza Ribeiro v France, Application No. 22689/07, para. 82; ECtHR, Judgment (GC), 15 November 1996, Chahal v United Kingdom, Application No. 22414/93, para. 151; ECtHR, Judgment, 11 July 2000, Jabari v Turkey, Application No. $40035 / 98$. 
ably prompt fashion, ${ }^{105}$ as well as the right to sufficient information, ${ }^{106}$ including that to interpreters and legal advisers. ${ }^{107}$

In all expulsion cases - including those where article 13 is claimed in connection with article 4 protocol 4 ECHR, the right to an effective remedy guarantees access to a domestic remedy before the execution of the expulsion. ${ }^{108}$ In other words, a hasty expulsion which does not allow an applicant to avail herself of a remedy and the relevant judicial authority to examine and rule before the expulsion will be in breach of article 13 ECHR.

\section{The Prohibition of Collective Expulsions in Other Regional Human Rights Instruments}

The prohibition of collective expulsions is also guaranteed within the (1) American and (2) African human rights systems.

105 ECtHR, Judgment (GC), 13 December 2012, De Souza Ribeiro v France, Application No. 22689/07, para.82; ECtHR, Judgment, 3 June 2004, Batı and Others $v$ Turkey, Application No. 33097/96, para. 136; ECtHR, Judgment (GC), 21 January 2011, M.S.S. v Belgium and Greece, Application No. 30696/09, para. 320.

106 ECtHR, Judgment (GC), 23 February 2012, Hirsi Jamaa and Others v Italy, Application No. 27765/09, para. $203 \mathrm{ff}$;; ECtHR, Judgment (GC), 21 January 2011, M.S.S. $v$ Belgium and Greece, Application No. 30696/09, para. 304.

107 ECtHR, Judgment (GC), 23 February 2012, Hirsi Jamaa and Others v Italy, Application No. 27765/09, para. 202; ECtHR, Judgment, 21 October 2014, Sharifi and Others $v$ Italy and Greece, Application No. 16643/09, para. 168; ECtHR, Judgment (GC), 21 January 2011, M.S.S. v Belgium and Greece, Application No. 30696/09, para. 301.

108 ECtHR, Judgment, 25 June 2020, Moustahi v France, Application No. 9347/14, para. 161; ECtHR, Judgment (GC), 13 December 2012, De Souza Ribeiro v France, Application No. 22689/07, para. 94 f.; ECtHR, Judgment, 15 May 2012, Labsi v Slovakia, Application No. 33809/08, para. 139; ECtHR, Judgment (GC), 15 December 2016, Khlaifia and Others v Italy, Application No. 16483/12, para. 280. This is in line with jurisprudence from the UN Treaty Bodies on this point. See in particular UN CAT, Communication No. 63/1997, Josu Arkauz Arana v France, 9 November 1999, UN Doc. CAT/C/23/D/63/1997, para. 6.1; UN CAT, Сommunication No. 300/2006, Tebourski $v$ France, 11 May 2005, UN Doc. CAT/C/38/D/300/2006, para. 7.3 f.; UN Human Rights Committee ('UN HRC'), Communication No. 193/1985, Giry $v$ France, 20 July 1990, UN Doc. CCPR/C/39/D/193/1985; UN HRC, Communication No. 289/1988, Wolf v Panama, 26 March 1992, U.N. Doc. CCPR/C/44/D/289/1988, para. 5.2. 


\section{The American Convention on Human Rights}

The prohibition of collective expulsions of aliens is stipulated under article 22(9) of the American Convention in exactly the same words as under article 4 protocol 4 ECHR. The prohibition is one of the procedural and substantial guarantees protecting non-nationals - irrespective of legal status - from arbitrary expulsions. ${ }^{109}$

The first two cases in which the Inter-American Commission considered group expulsions were The Haitian Center for Human Rights et al. v. United States ('the Haitian Interdiction Case') ${ }^{110}$ and John Doe et al. v. Canada. ${ }^{111}$ Both cases were not considered under the American Convention but rather under the American Declaration of the Rights and Duties of Man - which does not contain a prohibition of collective expulsion - as the respondent states in the respective cases had only ratified the latter. The Haitian Interdiction Case addressed a U.S. policy by which boats from Haiti were intercepted in the high sea by U.S. authorities and forced back to Haiti, ${ }^{112}$ thus not only impeding access to protection in the U.S. but also in other countries. ${ }^{113}$ In the Haitian Interdiction Case, the Commission found that the U.S. had jurisdiction over those intercepted, grounding its finding in a UNHCR Amicus Brief on the jurisdictional scope of the nonrefoulement principle. ${ }^{114}$ The Commission concluded that the U.S. policy was inter alia in breach of the right to resort to the courts, the right to equality before the law and the right to seek and receive asylum. ${ }^{115}$ In John Doe et al. v. Canada, the Commission considered the Canadian 'direct

109 Additional procedural guarantees which have been successfully claimed include the right to a fair trial, including judicial guarantees and protection under article 8 and the right to non-discrimination under article 1(1). Substantial rights successfully claimed by non-nationals include the right to life (article 4) and humane treatment (article 5). See Inter-American Court of Human Rights ('IACtHR'), 24 October 2012, Case of Nadege Dorzema et al. $v$ Dominican Republic, Series C No. 251, para. 66; IACtHR, 28 August 2014, Case of Expelled Dominicans and Haitians $v$ Dominican Republic, Series C No. 282, para. $406 \mathrm{f}$.

110 Inter-American Commission for Human Rights ('IAComHR'), The Haitian Center for Human Rights et al. $v$ United States, 13 March 1997, Report No. 51/96.

111 IAComHR, John Doe et al. v Canada, 21 July 2011, Report No. 78/11.

112 For more details on this policy, see Gutekunst, 'Interdiction of Haitian Migrants on the High Sea: a Legal and Policy Analysis' (1984) 10 Yale Journal of International Law, 150.

113 IAComHR, The Haitian Center for Human Rights et al. $v$ United States, 13 March 1997, Report No. 51/96, para. 161.

114 Id., para. 157.

115 Id., paras. $183-8$. 
back policy,' by which persons who sought asylum at the Canadian-U.S. border were sent back to the U.S. until their asylum interview date, but without assurances that the U.S would not deport them further. In this case, the Commission also found violations of the right to seek asylum and to resort to courts, as well as the right to protection from possible chain refoulement. ${ }^{116}$

It is against this backdrop of cases that the Inter-American Court found its first violation of the prohibition of collective expulsions under article 22(9) of the American Convention in Case of Nadege Dorzema et al. $v$. Dominican Republic. ${ }^{117}$ The case addressed the violent summary expulsions by Dominican officers of a group of Haitian migrants who had entered the Dominican Republic irregularly. In its assessment of the state's obligations under article 22(9), the Court found that the prohibition of collective expulsions was part of a set of rights expressed under article 22 which constituted an essential condition to the free development of human beings. ${ }^{118}$ Furthermore, the Court highlighted that the essential criterion to the characterisation of a collective expulsion was not the number of non-nationals expelled but the lack of an individualised expulsion proceedings. ${ }^{119}$ Then the Court defined minimal procedural guarantees to be applied without any discrimination as to status. These include: the right to be formally and expressly informed of the grounds for expulsion; the right to state one's case and contest the state's case; the right to legal assistance, interpretation and consular representation; the right to have an unfavourable decision reviewed by a competent authority; and the right to a notified and reasoned decision. ${ }^{120}$

The second case in which the Court found a violation of article 22(9) of the Convention is the Case of Expelled Dominicans and Haitians $v$. Dominican Republic. ${ }^{121}$ The case addressed a 1990s systematic practice of expulsion of Haitians and Dominicans of Haitian descent from the Dominican Republic. ${ }^{122}$ The Court noted that these expulsions, 'affected

116 IAComHR, John Doe et al. v Canada, 21 July 2011, Report No. 78/11, para. 128.

117 IACtHR, 24 October 2012, Case of Nadege Dorzema et al. $v$ Dominican Republic, Series C No. 251.

118 Id., para. 169.

119 Id., para. $172 \mathrm{ff}$.

120 Id., para. 175.

121 IACtHR, 28 August 2014, Case of Expelled Dominicans and Haitians v Dominican Republic, Series C No. 282.

122 Id., para. 171. 
nationals and aliens alike, both documented and undocumented [...]. ${ }^{123}$ Before addressing the prohibition of collective expulsions, the Court summarised its view on applicable standards in expulsion proceedings. Drawing from its Advisory Opinion on the Juridical Condition and Rights of the Undocumented Migrants, ${ }^{124}$ the Court highlighted that, 'due process must be guaranteed to everyone, regardless of their migratory status.' 125 In this section, the Court reiterated the procedural safeguards it had listed in Nadege Dorzema. ${ }^{126}$ In considering the prohibition of collective expulsions, the Court once more highlighted that the prohibition, 'stems from the considerations on due process of law in immigration proceedings. ${ }^{127}$ It confirmed that the essence of the prohibition was to guarantee, 'an objective analysis of the individual circumstances of each alien.' In doing so the Court referred to the ECtHR's definition of a collective expulsion from the cases of Andric $v$. Sweden ${ }^{128}$ and Conka v. Belgium. ${ }^{129}$

The American Convention contains procedural and substantive rights which can be invoked to ensure that non-nationals have their cases individually considered before being expelled. ${ }^{130}$ Yet the Inter-American Court of Human Rights has clearly connected the prohibition of collective expulsions to the right to due process, whilst underscoring that such due process rights are not to be underestimated for being only procedural. To the contrary, they constitute core human rights.

123 Id., para. 330.

124 IACtHR, 17 September 2003, Juridical Condition and Rights of the Undocumented Migrants, Advisory Opinion, Series A No.18.

125 IACtHR, 28 August 2014, Case of Expelled Dominicans and Haitians v Dominican Republic, Series C No. 282, para. 351.

$126 I d$, para. 356.

127 Id., para. 361. This connection between the right to due process and the prohibition of collective expulsions had already been made by the Court in IACtHR, 24 October 2012, Case of Nadege Dorzema et al. v Dominican Republic, Series C No. 251, para. 176.

128 ECtHR, Judgment, 23 February 1999, Andric $v$ Sweden, Application No. 45917/99.

129 ECtHR, Judgment, 5 February 2002, Conka v Belgium, Application No. 51564/99.

130 For example, in IACtHR, 24 October 2012, Case of Nadege Dorzema et al. $v$ Dominican Republic, Series C No. 251, para. 66, the Court also found violations of the right to judicial guarantee under article $8(1)$ and to judicial protection under article 25 (an equivalent of the right to an effective remedy under article 13 ECHR) of the American Convention, inter alia. 


\section{The African Charter on Human and Peoples' Rights}

Article 12(5) of the African Charter ('the Charter') stipulates that 'the mass expulsion of non-nationals shall be prohibited. Mass expulsion shall be that which is aimed at national, racial, ethnic or religious groups.' This provision has two particularities. First, it uses the word 'mass' rather than 'collective'. ${ }^{131}$ Second it defines characteristic discriminatory grounds for the expulsion to qualify as en masse. In practice, the African Commission on Human and Peoples' Rights does not impose such requirements when applying this article.

Here again, the prohibition is one of many procedural and substantial guarantees protecting non-nationals - irrespective of legal status - from arbitrary expulsions. ${ }^{132}$

The Commission's first finding of a violation of the prohibition of mass expulsions addressed the mass expulsion of Burundian refugees from Rwanda. ${ }^{133}$

Then the Commission found a violation of article 12(5) of the Charter in relation to the apprehension, detention and expulsion over a period of

131 As pointed out by Riemers, this difference is not significant and in fact the French version of the Charter uses the word 'collective'. See Riemers, The Prohibition of Collective Expulsion in Public International Law (2020),17 ff.

132 The main and most crucial additional procedural guarantee as acknowledged by the ACPHR jurisprudence is the right to appeal to a competent national organ (article 7). This stands in contrast to the position under the ECHR and the ECtHR's jurisprudence, where the applicability of the right to a fair hearing under article 6 ECHR has been excluded for immigration issues. See ECtHR, Judgment (GC), 5 October 2000, Maaouia v France, Application No. 39652/98, para. 35; Substantial rights successfully claimed by non-nationals in the context of their arbitrary expulsions include the prohibition of discrimination (article 2 ), the right to life and integrity (article 4), the right to human dignity and the prohibition of torture, cruel, inhuman or degrading treatment (article 5), the right to family life (article 18). See African Commission for Human and Peoples' Rights ('ACHPR'), Organisation Mondiale Contre la Torture and Others $v$ Rwanda, October 1996, 27/89; ACHPR, African Institute for Human Rights and Development $v$ Guinea, 23 November to 7 December 2004, 249/2002; ACHPR, Rencontre africaine pour la défence des droits de l'Homme (RADDHO) v Zambia, 31 October 1997, 71/92; ACHPR, Union Inter-Africaine des Droits de l'Homme et al. $v$ Angola, 11 November 1997, 159/96.

133 ACHPR, Organisation Mondiale Contre la Torture and Others $v$ Rwanda, October 1996, 27/89. The Commission also found a violation of article 12(5) of the Charter further to the mass expulsion of refugees in ACHPR, African Institute for Human Rights and Development v Guinea, 23 November to 7 December 2004, 249/2002. 
two months of over 500 non-nationals which the respondent state claimed were staying irregularly on its territory. Thus in Rencontre Africaine pour la Défense des Droits de l'Homme (RADDHO) v. Zambia, ${ }^{134}$ though the Commission agreed that the respondent state had the right to expel non-nationals staying irregularly, it held that such expulsions had to comply with certain requirements. ${ }^{135}$ In particular, the Commission found violations of the prohibition of mass expulsion. Importantly the Commission ruled that the fact that these non-nationals had been apprehended, served with detention orders and detained in different places and at different times over a period of two months did not exclude that the expulsions were en masse because the respondent state could not 'prove that the deportees were given the opportunity to seek appeal against the decision on their deportation. ${ }^{136}$ In many ways, the situation of the applicants was factually similar to the one in the ECtHR case of Khlaifia and Others $v$. Italy, ${ }^{137}$ but unlike the ECtHR, the African Commission allocated responsibility to the state to prove that the applicants could have challenged their deportations in practice. A further crucial finding was that the Commission defined the characteristic discriminatory grounds very broadly, finding that it was enough that, 'West Africans constituted the majority of those expelled.'138

This jurisprudence was reaffirmed shortly after, in a third case, relating to a practice of mass expulsions of West Africans from Angola. ${ }^{139}$ In Union Inter-Africaine des Droits de l'Homme et al. v. Angola, the Commission found a violation of article 12(5) of the Charter. In doing so, it specifically addressed the expulsion of undocumented migrants and highlighted that it could not happen without any procedural guarantees. ${ }^{140}$ Importantly the Commission stated that mass/collective expulsions, 'constitute a special

134 ACHPR, Rencontre africaine pour la défence des droits de l'Homme (RADDHO) $v$ Zambia, 31 October 1997, 71/92.

135 Id., para. 23.

$136 I d$., para. $27 \mathrm{f}$.

137 ECtHR, Judgment (GC), 15 December 2016, Khlaifia and Others $v$ Italy, Application No. 16483/12.

138 ACHPR, Rencontre africaine pour la défence des droits de l'Homme (RADDHO) $v$ Zambia, 31 October 1997, 71/92, para. 26.

139 Id., para. 11. This jurisprudence was further confirmed in ACPHR, Institute for Human Rights and Development in Africa v Angola, 7 to 22 May 2008, 292/04, paras. $35 \mathrm{f}$. and $67 \mathrm{ff}$.

140 ACHPR, Union Inter-Africaine des Droits de l'Homme et al. $v$ Angola, 11 November 1997, 159/96, para. 20. 
violation of human rights' ${ }^{141}$ which 'calls into question a whole series of rights recognized and guaranteed in the Charter'.

\section{E. Conclusion}

The prohibition of collective expulsions as initially intended by the drafters of the $4^{\text {th }}$ protocol to the ECHR ensures a very minimal and basic right, namely the right to be treated as an individual - as a legal subject rather than a mere object of the law. ${ }^{142}$ By denying its applicability to undocumented migrants crossing borders irregularly, ${ }^{143}$ the Strasbourg Court may be denying their very humanity. It certainly places its jurisprudence in an interpretative dissonance with its American and African counterparts. This dissonance results partially from the perception and treatment of undocumented migrants - as often opposed to refugees - by these institutions. Where Strasbourg takes a punitive stance, ${ }^{144}$ both the Inter-American Court and the African Commission consider undocumented migrants as a particularly vulnerable category requiring specific protection. ${ }^{145}$

Scholars have examined the failure of international human rights law to protect the basic rights of undocumented migrants, thus echoing Hannah Arendt's analysis on 'the right to have rights. ${ }^{146}$ In a concurring judgement on access to rights at borders, former ECtHR judge Pinto de Albuquerque stated, 'To allow people to be rejected at land borders and returned without assessing their individual claims amounts to treating

141 Id., para. 19.

142 In that sense, the prohibition of collective expulsions is one of the concrete expressions of the right to juridical personality, as first embodied under article 6 of the Universal Declaration of Human Rights but also within article 16 of the Convention for Civil and Political Rights.

143 See ECtHR, Judgment (GC), 15 December 2016, Khlaifia and Others $v$ Italy, Application No. 16483/12; ECtHR, Judgment (GC), 13 February 2020, N.D. and N.T. $v$ Spain, Application Nos. 8675/15 and 8697/15.

144 Pichl and Schmalz, "Unlawful” may not mean rightless', Verfassungsblog, 14 February 2020, https://verfassungsblog.de/unlawful-may-not-mean-rightless.

145 IACtHR, 24 October 2012, Case of Nadege Dorzema et al. v Dominican Republic, Series C No. 251, para. 152; ACHPR, Open Society Justice Initiative v Côte d'Ivoire, 25 February 2016, 318/06, para. 141.

146 See Ramji-Nogales, “The Right to Have Rights”: Undocumented Migrants and State Protection' (2015) 63 Kansas Law Review, 1045. 
them like animals. Migrants are not cattle that can be driven away like this. ${ }^{147}$

This principle is deeply grounded in post-World War II values. In the late 1940s, René Cassin advocated for the inclusion of the right to legal personality in order to avoid historical repetitions by which humans, 'were once considered as instruments, as chattels, not as beings who could have rights. ${ }^{148}$ Sadly, Cassin's concerns remain relevant. In this case the failure of human rights to protect the whole of humanity does not find its cause in imperfect legal provisions, but rather in the historical and social constructs - and bias - of those interpreting the law.

\section{Bibliography}

Christides, Giorgos/Lüdke, Steffen/Popp, Maximilian: The Killing of a Migrant at the Greek-Turkish Border', SPIEGEL International, 8 May 2020, https://www.spiegel.de/international/europe/greek-turkish-borderthe-killing-of-muhammad-gulzar-a-7652ff68-8959-4e0d-9101-a1841a944161.

Ciliberto, Giulia: A Brand-New Exclusionary Clause to the Prohibition of Collective Expulsion of Aliens: The Applicant's Own Conduct in N.D. and N.T. v Spain, Hum. Rights Law Rev. 2021, $203 \mathrm{ff}$.

Gericke: Zwischen effektivem Menschenrechtsschutz und Realpolitik. Die jüngere Rechtsprechung des EGMR zum Rechtsschutz an den EU-Außengrenzen, Asylmagazin, Zeitschrift für Flüchtlings-und Migrationsrecht 2020, 14ff.

Goldner Lang, Iris: Which Connection between the Greek Turkish Border, the Western Balkans Route and the ECtHR's judgment in ND and NT?, 4 September 2020, http://eumigrationlawblog.eu/2750-2/.

Gutekunst, Claire P.: Interdiction of Haitian Migrants on the High Sea: a Legal and Policy Analysis, Yale Journal of International Law 1984, 150ff.

Hathaway, James C./Gammelthoft-Hansen, Thomas: Non-Refoulement in a World of Cooperative Deterrence, Colum. J. Transnat'l L. 2015, $235 \mathrm{ff}$.

ILC, Draft articles on the expulsion of aliens, with commentaries (2014), https:// legal.un.org/ilc/texts/instruments/english/commentaries/9_12_2014.pdf.

147 ECtHR, Judgment, 11 December 2018, M.A. and Others $v$ Lithuania, Application No. 59793/17, Dissenting Opinion, para. 54.

148 UN Economic and Social Council, Record of the Eighth Meeting of the Drafting Committee of the Commission on Human Rights, 17 June 1947, UN Doc. E/CN.4/ AC.1.SR.8, $7 \mathrm{f}$. 
Juezas y Jueces para la Democracia: Comunicado de JJpD acerca de la decisión del TEDH sobre las devoluciones en caliente: EUROPA SE BLINDA, 14 February 2020, http://www.juecesdemocracia.es/2020/02/14/comunicado-jjpd-acerca-la-de cision-del-tedh-las-devoluciones-caliente-europa-se-blinda/.

Lübbe, Anna: The Elephant in the Room, Verfassungsblog, 19 February 2020, https:/verfassungsblog.de/the-elephant-in-the-room/.

Markard, Nora: A Hole of Unclear Dimensions: Reading ND and NT v. Spain, 1 April 2020, https://eumigrationlawblog.eu/a-hole-of-unclear-dimensions-reading-nd-and-nt-v-spain/.

Oviedo Moreno, Carlos: A Painful Slap from the ECtHR and an Urgent Opportuniy for Spain, Verfassungsblog, 14 February 2020, https://verfassungsblog.de/apainful-slap-from-the-ecthr-and-an-urgent-opportunity-for-spain/.

Papageorgopoulos, Stavros: N.D. and N.T. v. Spain: do hot returns require cold decision-making?, EDAL - European Database of Asylum Law, 28 February 2020, https:/www.asylumlawdatabase.eu/en/journal/nd-and-nt-v-spaindo-hot-returns-require-cold-decision-making.

Pichl, Maximilan/Schmalz, Dana: "Unlawful" may not mean rightless, Verfassungsblog, 14 February 2020, https://verfassungsblog.de/unlawful-may-notmean-rightless/.

Ramji-Nogales, Jaya: "The Right to Have Rights": Undocumented Migrants and State Protection, Kansas Law Review 2015, $1045 \mathrm{ff}$.

Riemers, Lena: The Prohibition of Collective Expulsion in Public International Law (2020).

Thym, Daniel: A Restrictionist Revolution?, Verfassungsblog, 17 February 2020, https://verfassungsblog.de/a-restrictionist-revolution/.

UN CAT: General Comment No. 4 (2017) on the implementation of article 3 of the Convention in the context of article 22, UN Doc. CAT/C/GC/4, 9 February 2018.

UN General Assembly, International Law Commission: Third report on the expulsion of aliens. By Mr. Maurice Kamto, Special Rapporteur, UN Doc. A/ CN.4/581, 19 April 2007.

UN Economic and Social Council: Record of the Eighth Meeting of the Drafting Committee of the Commission on Human Rights, UN Doc. E/CN.4/AC.1.SR.8, 17 June 1947.

UNHCR: Submission by the Office of the United Nations High Commissioner for Refugees in the cases of N.D. and N.T. v. Spain (Appl. Nos 8675/15 and 8697/15) before the European Court of Human Rights, 15 November 2015, https://www.unhcr.org/protection/operations/5f9ab8794/unhcr-interventions-eu ropean-court-human-rights.html. 
